INSULIN-LIKE GROWTH FACTORS (IGE), PLACENTAL LACTOGEN

99 (PL), INSULIN (InS) AND SUBSTRATES IN THE PREGNANT EWE AND NEWBORN LAMB. Peter D. Gluckman, John H. Butler and Thomas $\mathrm{N}$. Barry , University of Auckland, Dept. of Paediatrics Auckland, and *Invermay Agricultural Research Centre, Mosgejl. New Zealand.

The regulation of $X$ GF secretion in pregnancy and in the fetus is poorly understood. 10 triplet bearing ewes were fed maintainance plus control abomasal infusion $(n=3)$, plus glucose infusion $(n=3)$, plus casein $(n=2)$, plus glucose and casein $(n=2)$ through the last 42 days of gestation to provide a range of substrate availability. Birth weight (BW) was not affected. 18-27 days before birth, multiple maternal plasma samples were taken at fixed times relative to meals. Maternal PL levels were decreased by casein ( $p(0.05)$ but not by glucose infusion. A negative correlation $(p<0.05)$ was seen between PL and IGF-1 (by RIA) $(r=-0.72$ ). There was a positive correlation between PL and IGF-2 (by rat placental RRA) $(r=0.64)$. There was a strong inverse correlation between maternal IGF-1 and IGF-2 $(x=-0.94)$. The correlation between nonesterified free fatty acids and the IGF-2/IGF-1 ratio was 0.81 . A similar correlation to PL was 0.66 . There was a correlation $(p<0.05)$ between cord $I G F-1$ levels and $B W$. Multiple linear regression showed an interaction between cord IGF-1. Ins and $B W(p<0.001$ ) which explained $63 \%$ of the variation in $B W$. These findings suggest an interaction in the late gestation ewe between the relative secretion of IGF-1 and IGF-2, metabolic status and PL secretion. IGF-2 may be the mediator of the lipolytic action of PL. The neonatal observations support the concept that fetal IGF- 1 and Ins are important detirminants of fetal growth.
100 RECEPTOR BTNDING OF SOMATOMEDIN/INSULIN-LIKE GROWTH FACTORS (Sm/IGFS) ON CULTURED RAT ASTROGLIAL CELLS. Victor K.M. Han*, A. Joseph D'Ercole*, Jean M. Lau$\mathrm{der}^{+}$and Marjorie E. Svoboda*, Departments of Pediatrics* and Anatomy ${ }^{+}$University of North Carolina, Chapel Hill, NC, U.S.A. In previous studies, we identified binding sites for Sm/IGFs on cultured astroglial cells purified from neonatal rat cerebral cortices by high resolution autoradiography. To further characterize these binding sites, we performed traditional binding studies. Binding for each $\mathrm{Sm} / \mathrm{IGF}$ is specific, saturable and reversible, and $90 \%$ of the binding occurs within 6 hours at $4^{\circ} \mathrm{C}$. Competitive binding with $\mathrm{Sm-C/IGF-I} \mathrm{yields} \mathrm{curvilinear} \mathrm{Scatchard}$ plots, while studies with IGF-II and MSA yields linear plots, suggesting that two receptor species bind $\mathrm{Sm}-\mathrm{C} / \mathrm{IGF}-\mathrm{I}$ and one binds IGF-II and MSA. These findings are supported by affinity crosslinking studies with labeled Sm/IGFs, using disuccinimidyl suberate as a crosslinking agent, followed by solubilization, reduction and analysis on SDS PAGE. ${ }^{125} \mathrm{I}-\mathrm{Sm}-\mathrm{C} / \mathrm{IGF}-\mathrm{I}$ bind to moieties with $\mathrm{Mr}$ of $260 \mathrm{~K}$ (the type II receptor) and $130 \mathrm{~K}$ (a subunit of the type I receptor), while 125 I-IGF-II and ${ }^{125}$ I-MSA binds primarily to the $\mathrm{Mr} 260 \mathrm{~K}$ moiety. Concurrent studies of $\mathrm{Sm} /$ IGF stimulation of ${ }^{3} \mathrm{H}$-thymidine incorporation into astroglial cells reveal that both IGF-II and MSA are more potent that $\mathrm{Sm}-\mathrm{C} / \mathrm{IGF}-\mathrm{I}$. These data suggest that astroglial cells possess bot type I and type II Sm/IGF receptors and that proliferation in response to $\mathrm{Sm} / \mathrm{IGFs}$ can be mediated through type II receptors.
PROSPECTIVE, RANDOMIZED TRIAL OF METHIONYL HUMAN

102 GROWTH HORMONE AND/OR OXANDROLONE IN TURNER SYNDROME. Ron G. Rosenfeld, Raymond L. Hintz, Ann J. Johanson, and the Genentech Collaborative Group, Stnaford University School of Medicine, Department of Pediatrics, Stanford, California, USA.

To evaluate the efficacy of methionyt human growth hormone ( $h G H)$ and oxandrotone (OX), alone and in combination (COMB), in the treatment of Turner syndrome, 71 patients were entered into a randomized, prospective study. After a 6-month observation period, subjects were randomly assigned to either no treatment (CONTROL), OX $(0.125 \mathrm{mg} / \mathrm{kg} / \mathrm{day}), \mathrm{hGH}(0.125 \mathrm{mg} / \mathrm{kg}$ tiw) or COMB. The table shows mean growth rates in $\mathrm{cm} / \mathrm{yr} \pm S D(\mathrm{n})$ :

\begin{tabular}{|c|c|c|c|}
\hline & Basel ine & 6 months & 12 months \\
\hline CONTROL & $4.2 \pm 1.1(18)$ & $3.5 \pm 1.8$ (18) & $3.2 \pm 0.4$ \\
\hline & $4.3 \pm 1.1$ (19) & $7.6 \pm 1.4^{\star}(15)$ & $8.2 \pm 1.0^{*}$ \\
\hline hGH & $4.5 \pm 0.8(17)$ & $7.1 \pm 1.3^{*}(15)$ & $6.6 \pm 1.4^{*}$ \\
\hline COMB & $4.3 \pm 0.9(17)$ & $10.1 \pm 1.8^{*}(15)$ & $10.0 \pm 1.8^{*}$ \\
\hline
\end{tabular}

* $p<0.0001$ compared to control

Al1 treatment modalities resulted in significant growth acceler ation over baseline, and growth velocities were significantly greater than in the control group at both 6 and 12 months ( $p<$ 0.0001 ). COMB was superior to either OX or hGH at both 6 and 12 months $(p<0.05)$. The mean advance in bone age at 6 months was: CONT 0.2 yrs, OX $0.5 \mathrm{yrs}$, hGH $0.4 \mathrm{yrs}$, COMB $0.4 \mathrm{yrs}$. No significant adverse effects of any treatment modality have been observed to date. These data indicate that hGH, alone or in combination with oxandrolone, promotes short term growth acceleration in Turner syndrome.

\section{SYNDROME (TS).}

Nikolaus Stahnke, Kathrin Lingstaedt, Rolf P. Willig. University of Hamburg, Department of Pediatrics, Germany, FRG. 29 pat. with TS were studied: 20 pat. With 45 , X0 karyotyping ( $g r \circ u p$ I): mean chronol. age (CA) $14.1 \pm 0.5$ (SEM), bone age (BA) $11.1 \pm 0.3$ yrs., 9 pat. were mosaics ( $g r$ o u $p$ II): mean $C A 14.2+0.6$, BA $12.0+0.4$ yrs. Oxandrolone dosage was $0.1 \mathrm{mg} / \mathrm{kg} /$ day, treatment period was 1 to 6 years.

In $\mathrm{g} r$ o u $\mathrm{p}$ I pretreatment growth velocity (GV) $2.8+0.3$ increased to $5.3+0.3$ and $5.0+0.3 \mathrm{~cm} / \mathrm{yr}$. during first and second 6 months of therapy (TH). A fterwards GV slowly declined to $2.1 \pm 0.4$ after 5 yrs. of TH. BA velocity was $0.71 \pm 0.1$ "yrs." $\mathrm{yr}$. during first year of $\mathrm{TH}$, declining to $0.21 \pm 0 . \overline{0} 7$ at 5 yrs. of TH. Pretreatment height age/BA ratio $0.86+0.02$ was increased to 0.92. Pretreatment height standard deviation score (SDS) for $\mathrm{CA}-3.34+0.17$ was reduced to $-2.63+0.41$ at $5 \mathrm{yrs}$. Of $\mathrm{TH}$, pretreatment height SDS for BA $-1.39+0 . \overline{1} 7$ was diminished to $-1.02 \pm 0.32$. In 11 of 20 pat. TH was finished after 4.0 years $(1.5-6.0)$ :CA $18.1+0.4, B A 13.4 \pm 0.1$ yrs., height $149.2 \mathrm{~cm}$ $(143.4-155.5 \mathrm{~cm})$, height SDS $(\mathrm{CA})^{-}-2.17 \pm 0.19$. In 6 of these 11 pat. height was above $150 \mathrm{~cm}$. Similar büt less pronounced results were found in $g r$ o u $\mathrm{p}$ II. - There was a significant negative correlation between pretreatment $B A$ and GV under oxandrolone in all TS pat. $(r=-0.61, p<0.001)$. - Side effects: In 6 of 29 pat. a smail transient increase in transaminases.

Thus, oxandrolone improved final height in many pat. with TS.
LONG-TERM FOLLOW UP OF 2 CASES OF MIXED GONADAL DYS-

03 GENESIS (MGD) : TRAGIC CONSEQLENCES OF REARING IN MALE

GENDER. E.de Peretti, M.David*and M.G.Forest. INSERMU.34 and Pediatric Clinic, Hôpital Debrousse, Lyon, France.

Two boys, now $20 \mathrm{yr}$ old, were seen at birth for ambigous genitalia(hypospadias stade III); only 1 gonad was palpated in an inguinal hernia; karyotypes were $46, \mathrm{XO} / \mathrm{XY}$. At laparotomy, sma11

vagina, uterus; one small testis on one side, a streak and a fallopian tube on the other side. In boy $\mathrm{n}^{\circ} 2$ a gonocytoma was found in the streak. However, because at histology the testis appeared immature but normal, both were kept in the male gender. Streaks and Mullerian structures were removed. Both presented several of the classical somatic abnormalities observed in Turner's syndrome and a very poor growth rate as well. At age 3, plasma testosterone(T) rose only to 415 and $220 \mathrm{ng} / \mathrm{dl}$ after hCG test. In both, plastic reconstruction of genitalia was difficult, particularly in boy $\mathrm{n}^{\circ} 2$, with repetitive surgeries until age 10 . In boy $n^{\circ} 1$, the tes tis progressively vanished, LH/FSH rose, gynecomastia developped, achievement of puberty required substitutive $\mathrm{T} \mathrm{Rx}$. At $19 \mathrm{yr}$, the testicular remnant was removed and 2 prostheses put in scrotum. In boy $\mathrm{n}^{\circ} 2$, $\mathrm{T}$ rose to $730 \mathrm{ng} / \mathrm{dl}$ at $15 \mathrm{yr}$ at the price of very high LH/FSH levels, but subsequently declined and substitutive $\mathrm{T} R \mathrm{Rx}$ needed at age 18. In conclusion, the choice of sex, made $20 \mathrm{yr}$ ago at a time when MGD was about first recognized, was a mistake. Tragic results are 1) very short stature (final height 145 and 147 cms); 2) difficult and unsatisfactory reconstructive surgery; 3) a progressive vanishing testis and deficient Leydig and Sertoli cells functions suggesting that the apparently normal testis was also dysgenetic. Supported by INSERM grant (PRC 129047). EFFECT OF ESTRADIOL TREATMENT MONITORED BY SERUM CON CENTRA.

Turner study group (Intr, by Knud w Kastrup), Endocrine clinic, Dept. of Pea., Fuglebakken and Hvidovre Hosp., Copenhagen,

A low-dose $17 \beta$-estradiol (17B-e) therapy was given to 33 girls with Turner syndrome (T.s.). As dose schedules previously used have been empirical and occasionally with undesirable effects, was the dose of $173-e(0.25-2 \mathrm{mg} /$ day $)$ in the present study adjusted to the normal serum levels according to biological age with 3 mos intervals. Height and growth velocity curves for $T . s$. (Lenko et al.) were used for reference. In group I ( $n: 11$ ) with bone age less than 10 yr the mean duration of therapy was $37 \pm 13$ mos. In group II $(\mathrm{n}: 22)$ with bone age above $10 \mathrm{yr}: 38 \pm 11$ mos. SDS (velocity) in group I: $4.96,3.01$ and 1.53 , in group II: $4 . \overline{5,1.39}$ and -2.5 in first 3 yrs of therapy. Bone age velocity in group $I$ 38,13 and 16 mos/l $\mathrm{yr}$, in group II: 16,19 and $16 \mathrm{mos} / 1$ yr. Mean duration of therapy in development from Pub.stage 2 to 5 (mamma) was 4.5 to 36 mos (group I) and 3-32 mos (group II) and from Pub. Stage 2-4 (Pubes) 12-30 mos (group I) and 3-25 mos (group II). Menarche occurred after 23 mos of therapy in 18 girls (range 1533 mos). Final height in 18 girls after therapy was $145.2 \div 4.4$ $\mathrm{cm}$. Prediction (Index of potential height): $143.2 \pm 5.9 \mathrm{~cm}$. Gain in final height was also predicted at the end of 2 nd and $3 r d y r$. Summary: Estrogen therapy aimed to reproduce normal serum levels leads to near-normal pubertal development and to increased growth velocity without reduction in final height. 